\title{
Alpha-2-Globin Gene Polyadenylation (AATAAA $\rightarrow$ AATAAG) Mutation in Hemoglobin H Disease among Kuwaitis
}

\author{
M. Haider A. Adekile \\ Department of Pediatrics, Faculty of Medicine, Kuwait University, Kuwait
}

\author{
Key Words \\ Hemoglobin $\mathrm{H}$ disease $\cdot \alpha_{2}$-Globin gene \\ polyadenylation $\cdot$ Kuwait
}

\begin{abstract}
Objectives: In the Arabian Gulf region, hemoglobin ( $\mathrm{Hb})$ $\mathrm{H}$ disease usually results from homozygosity or compound heterozygosity involving the $\alpha_{2}$-globin gene polyadenylation (poly A) signal (AATAAA $\rightarrow$ AATAAG) mutation $\left(\alpha^{\top} \alpha\right)$. Here we document the clinical and hematological characteristics of children with $\mathrm{Hb} \mathrm{H}$ disease being followed in Kuwait. Subjects and Methods: Twentyfour patients $(0.5-12$ years old, mean $4.7 \pm 3.5$ years) with persistent microcytic, hypochromic anemia (and normal iron status as well as normal $\mathrm{Hb} \mathrm{A}_{2}$ levels) were referred to the pediatric hematology clinic for further investigations. They were all screened for the $\alpha^{+}$-thalassemia $\left(\alpha^{+}\right.$-thal; $\left.-3.7 \mathrm{~kb}\right)$ deletion using a standard PCR method. They were also screened for the $\alpha_{2}$-globin gene $\alpha^{\top} \alpha$ allele and the 5 nt deletion $\left(-\alpha^{5 n t}\right)$ in the first intervening sequence, which are common $\alpha$-thal alleles in this population. They were followed up for periods ranging from 2 to 8 years. Results: Of the 24 patients, $4(16.7 \%)$ also had sickle cell trait (Hb-AS), while $7(29.2 \%)$ were glucose-6-phosphate dehydrogenase deficient. Only 1 patient had significant hepatosplenomegaly and 1 developed gallstones. While none was on
\end{abstract}

\section{KARGER}

Fax +4161306 1234

E-Mail karger@karger.ch

www.karger.com
(C) 2005 S. Karger AG, Basel

1011-7571/05/0147-0073\$22.00/0

Accessible online at:

www.karger.com/mpp chronic transfusion therapy, 8 (33.3\%) had been transfused at least once and, in 3 instances, this was secondary to parvovirus B19+ve aplastic crisis. The $\alpha$-globin genotype was successfully determined in almost all patients. The results showed that $17(70.8 \%)$ patients were homozygous for the poly A mutation $\left(\alpha^{\top} \alpha / \alpha^{\top} \alpha\right), 6$ (25.0\%) were compound heterozygotes for this and the $\alpha^{+}$-thal $(-3.7 \mathrm{~kb})$ deletion $\left(-\alpha / \alpha^{\top} \alpha\right)$ and $1(4.2 \%)$ was undetermined. There were no significant differences in the phenotypes of the 2 genotypes and their hematological features were identical. Conclusions: $\mathrm{Hb} \mathrm{H}$ disease involving the poly $\mathrm{A}$ mutation is a mild thal intermedia phenotype among Kuwaitis. There are no serious complications and there is no need for regular blood transfusion.

Copyright $(2005$ S. Karger AG, Basel

\section{Introduction}

Normal individuals have two linked $\alpha$-globin genes on chromosome 16, with the genotype $\alpha \alpha / \alpha \alpha$. The two most common determinants of $\alpha$-thalassemia, $\alpha$-thal- 2 and $\alpha$-thal-1, result from the loss of one $(-\alpha /)$ or both (--/) $\alpha$-globin genes, respectively. The former is associated with $\alpha^{+}$, while the latter is associated with $\alpha^{0}$-thal trait. Compound heterozygosity of $\alpha^{0}$-thal and $\alpha^{+}$-thal alleles $(--/-\alpha)$ results in inactivation or loss of $3 \alpha$-globin genes, 
with significant $\alpha / \beta$-globin chain imbalance causing the clinical syndrome called hemoglobin $(\mathrm{Hb}) \mathrm{H}$ disease. Less common $\alpha$-thal determinants are nondeletional lesions in which a mutation on one or the other $\alpha$-globin gene $\left(\alpha^{\mathrm{T}} \alpha /\right)$ reduces the synthetic production of the affected gene. Homozygotes $\left(\alpha^{\mathrm{T}} \alpha / \alpha^{\mathrm{T}} \alpha\right)$ or compound heterozygotes $(-\alpha /$ $\left.\alpha^{\mathrm{T}} \alpha,--/ \alpha^{\mathrm{T}} \alpha\right)$ are also associated with the $\mathrm{Hb} \mathrm{H}$ phenotype of varying severity [1-4].

The clinical phenotype of $\mathrm{Hb} \mathrm{H}$ disease is quite heterogeneous, but is usually one of thal intermedia with mild to moderate microcytic, hypochromic anemia, usually not requiring regular blood transfusion. The excess $\beta$-globin chains form unstable tetramers $(\mathrm{Hb} \mathrm{H})$, which precipitate to form $\mathrm{Hb} \mathrm{H}$ inclusion bodies in peripheral red blood cells. An $\mathrm{H}$ band may also be demonstrable on electrophoresis or high-performance liquid chromatography. In the newborn period, $\gamma$-tetramers (Hb Bart's) are seen. There may be varying degrees of hepatosplenomegaly and skeletal deformities [3-6].

$\alpha$-Thal trait is quite prevalent in the Arabian Peninsula with the frequency of $\alpha$-thal-2 allele being as high as $40-60 \%$ in some areas [7-9]. While the $\alpha^{0}$-thal alleles are uncommon, the nondeletional, $\alpha_{2}$-globin polyadenylation (poly A; AATAA스 $\rightarrow$ AATAAG ) allele has been described in Eastern Saudi Arabia, United Arab Emirates and Kuwait [3, 4, 10-12]. There have been mainly anecdotal reports of $\mathrm{Hb} \mathrm{H}$ disease among Gulf Arabs [8-10], and the present communication is an account of cases that are being followed in the pediatric hematology clinic in Kuwait. It documents their clinical presentation, laboratory findings and molecular characterization. In addition, it looks at the influence (if any) of coexistent sickle cell trait and glucose-6-phosphate dehydrogenase (G6PD) deficiency on the phenotype.

\section{Subjects and Methods}

A total of 24 patients were studied, 14 males and 10 females aged between 6 months and 12 years with a mean age of $4.7 \pm 3.6$ years. Eleven $(45.8 \%)$ had weight and height of $\geq 50$ th centile. Their $\mathrm{Hb}$ ranged from 7.4 to $10.6 \mathrm{~g} / \mathrm{dl}(9.0 \pm 0.8)$, mean cell volume from 48.1 to $66.6 \mathrm{fl}(56.7 \pm 4.0)$ and mean cell hemoglobin from 15.7 to $21.2 \mathrm{pg}(18.4 \pm 1.4)$. All patients had inclusion bodies in their peripheral blood smears.

The patients were being followed in the pediatric hematology clinics of the Amiri and Mubarak Hospitals in Kuwait. Both are part of the teaching hospitals' complex of the Kuwait University Faculty of Medicine. The diagnosis of $\mathrm{Hb} \mathrm{H}$ disease was based on the finding of microcytic, hypochromic anemia in a child who did not have iron deficiency and whose $\mathrm{Hb}$ electrophoresis was not consistent with the $\beta$-thal syndrome. In addition, they all showed $\mathrm{Hb} \mathrm{H}$ inclusion bodies in more than $80 \%$ of the peripheral red blood cells following cresyl blue staining. Family screening was carried out and in all cases both parents had varying degrees of microcytic and hypochromic anemia.

Blood was drawn from all the patients by venepuncture; complete blood count was done with the Coulter electronic cell counter. A qualitative test for G6PD deficiency was used for screening the patients [13]. DNA was extracted by the method of Poncz et al. [14]. All the patients were screened for the $\alpha$-thal-2 $\left(-\alpha^{-3.7} \mathrm{~kb}\right)$ deletion with a PCR method [15]. The $\alpha_{2}$-globin gene region was again amplified and dot blotting was done followed by allele-specific hybridization with probes specific for the poly A mutation [4, 11], AATAA $\underline{A} \rightarrow$ AATAAG $\left(\alpha^{\mathrm{T}} \alpha /\right)$ and 5 nt deletion $\left(-\alpha^{-5 n t}\right)$ in the $5^{\prime}$ splice junction of the first intervening sequence [16]. These are the two nondeletional $\alpha$-thal alleles prevalent in this region [10-12].

All the patients had detailed physical examination and were followed regularly in the clinic. The patients received daily folic acid supplement; otherwise, no other routine treatment was given. Their charts were reviewed for this report and details of any hospitalization were obtained. Particular attention was paid to frequency of blood transfusion and any complications, e.g. aplastic crisis.

\section{Results}

Of the 24 patients studied, 7 (29.2\%) had G6PD deficiency, while 3 (12.5\%) had Hb AS (heterozygous normal /sickle-Hb). Eight (33.3\%) had been transfused at least once and none was on regular transfusion. Four (57.1\%) of the G6PD-deficient patients had been transfused; the difference in frequency was not significant $\left(\chi^{2}=1.0, \mathrm{p}>0.05\right)$. There were also no other significant differences in the hematological parameters among those with G6PD deficiency or $\mathrm{Hb} \mathrm{AS}$; this may be due to the small sample size.

Seventeen $(70.8 \%)$ were homozygous for the poly A mutation $\left(\alpha^{\mathrm{T}} \alpha / \alpha^{\mathrm{T}} \alpha\right)$ and $6(25.0 \%)$ were compound heterozygous for the $\alpha$-thal- 2 deletion and the poly A mutation $\left(-\alpha^{3.7} / \alpha^{\mathrm{T}} \alpha\right)$, while $1(4.2 \%)$ was undetermined. There were no significant differences in the hematological parameters among the homozygotes and the compound heterozygotes.

The patients did not show any common complication, but $1(4.2 \%)$, with genotype $\alpha^{\mathrm{T}} \alpha / \alpha^{\mathrm{T}} \alpha$, who was also G6PD deficient, had persistent hepatosplenomegaly, first noticed when he was about 6 months old and persisting at age 9 years. He was also transfused on 3 occasions in the first 2 years of life. Three (12.5\%) patients developed aplastic crisis secondary to parvovirus B19 infection. Four (16.7\%) patients had reactive thrombocytosis with platelet count ranging from 600 to $>1,000 \times 10^{9} / 1$ lasting for varying lengths of time. None had evidence of concurrent iron deficiency. Only 1 (4.2\%) patient had gallstones and required cholecystectomy. 


\section{Discussion}

$\mathrm{Hb} \mathrm{H}$ disease is indeed common in Kuwaitis with ancestral origin in Eastern Saudi Arabia [17]. The patients are usually referred to the pediatric hematology clinic because of significant hypochromic, microcytic anemia not responding to iron supplements and with normal $\mathrm{Hb} \mathrm{\textrm {A } _ { 2 }}$ levels, ruling out $\beta$-thal trait. Almost all cases involve the $\alpha_{2}$-globin gene AATAA $\underline{A} \rightarrow$ AATAA $\underline{G}$ mutation either as homozygotes or compound heterozygotes with the $-\alpha^{3.7 \mathrm{~kb}} \alpha$-thal deletion.

The phenotype of $\mathrm{Hb} \mathrm{H}$ disease among our patients is uniformly mild, with none of them requiring regular transfusions. Patients with chronic hemolytic anemia are prone to aplastic crisis following documented parvovirus B19 infection [18-20]. This was encountered in 3 of our patients; it was self-limiting in all cases, although they all required at least one blood transfusion. Four of the patients in this study showed evidence of transient reactive thrombocytosis. This appears to be nonspecific and accompanies the anemia of the disease.

Concomitant G6PD deficiency may be responsible for frequent hemolytic crisis in sickle cell disease. Its effect, if any, on the phenotype in $\mathrm{Hb} \mathrm{H}$ disease has not been widely documented. Sanna et al. [21] reported higher G6PD enzyme levels in patients with $\mathrm{Hb} \mathrm{H}$ disease and Öner et al. [22] did not see any effect of the enzyme deficiency on the hematological parameters of their patient. Similarly, we could not demonstrate any significant effects of G6PD deficiency on our patients and the frequency of blood transfusion was not significantly higher.

Matthay et al. [23] have suggested that sickle cell trait may modify $\mathrm{Hb} \mathrm{H}$ disease because the relatively low $\mathrm{Hb}$ A level reduces the availability of $\beta$-chains to form $\mathrm{Hb} \mathrm{H}$.
On the other hand, $\alpha$-thal trait is known to ameliorate the course of sickle cell disease, because intracellular concentration of $\mathrm{Hb} \mathrm{S}$ is low in patients with coexistent $\alpha$-thal trait $[24,25]$. It was therefore interesting that 3 of the $\mathrm{Hb}$ $\mathrm{H}$ patients in the present study had sickle cell trait. Two of them had $\mathrm{Hb} \mathrm{H}$ inclusions in more than $80 \%$ of their peripheral erythrocytes and 1 had in about $40 \%$. However, the baseline $\mathrm{Hb}$ level and other hematological parameters were not significantly different. We therefore cannot make a case for a modifying role for sickle cell trait in our $\mathrm{Hb} \mathrm{H}$ patients.

No specific treatment is offered to our $\mathrm{Hb} \mathrm{H}$ disease patients. Full family screening is carried out on all suspected cases to document complete cell count, iron status, $\mathrm{Hb}$ electrophoresis and $\alpha$-globin genotype. Genetic counseling is carried out and the affected patients are started on regular folic acid supplementation. Patients who maintain their $\mathrm{Hb}$ at $10 \mathrm{~g} / \mathrm{dl}$ and above are not followed in the clinic.

\section{Conclusions}

$\mathrm{Hb} \mathrm{H}$ disease involving the poly A mutation is a mild thal phenotype among Kuwait patients. There are no serious complications and they do not require regular blood transfusion.

\section{Acknowledgements}

The technical assistance of Mark D'Souza, Himadri Dalal and Jalaja Sukumaran is appreciated. This work was supported by Kuwait Research Administration grant MK034.

\section{References}

1 Higgs DR, Vickers MA, Wilkie AOM, Pretorius IM, Jarman AP, Weatherall DJ: A review of the molecular genetics of the human $\alpha$-globin gene cluster. Blood 1989;73:1081-1104.

12 Kazazian HH: The thalassemia syndromes: Molecular basis and prenatal diagnosis in 1990. Semin Hematol 1990;27:209-228.

-3 Pressley L, Higgs DR, Clegg JB, Perrine RP, Pembrey ME, Weatherall DJ: A new genetic basis for hemoglobin-H disease. N Engl J Med 1980;303:1383-1388

-4 Thein SL, Wallace RB, Pressley L, Clegg DJ, Weatherall DJ, Higgs DR: The polyadenylation site mutation in the $\alpha$-globin gene cluster. Blood 1988;71:313-319. $\checkmark 5$ Lui TC, Chiou SS, Lin SF, Chen TP, Tseng WP, Chen PH, Chang JG: Molecular basis and hematological characterization of $\mathrm{Hb} \mathrm{H}$ disease in Southeast Asia. Am J Hematol 1994; 45:293-297.

6 Weatherall DJ, Clegg JB: The Thalassemia Syndromes, ed 3. Oxford, Blackwell Publishing, 1981.

7 El-Hazmi MAF: Haemoglobin disorders: A pattern of thalassaemia and haemoglobinopathies in Arabia. Acta Haematol 1982;68:43-51.

-8 White JM, Byrne M, Richards R, Buchanan T, Katsoulis E, Weerasingh K: Red cell genetic abnormalities in Peninsular Arabs: Sickle haemoglobin, G6PD deficiency, and alpha and beta thalassaemia. J Med Genet 1986;23:245251.
9 El-Hazmi MAF: Hemoglobinopathies, thalassemias and enzymopathies in Saudi Arabia. Saudi Med J 1992;13:488-499.

10 El-Kalla S, Baysal E: Alpha thalassemia in the United Arab Emirates. Acta Haematol 1998; 100:49-53.

$\checkmark 11$ Adekile AD, Gu, L-H, Baysal E, Haider MZ, Al-Fuzae L, Aboobacker KC, Al-Rashied A, Huisman THJ: Molecular characterization of $\alpha$-thalassaemia determinants, $\beta$-thalassaemia alleles and $\beta S$ haplotypes among Kuwaiti Arabs. Acta Haematol 1994;92:176-181.

12 Adekile AD, Haider MZ: Morbidity, $\beta S$ haplotype and $\alpha$-globin gene patterns among sickle cell anemia patients in Kuwait. Acta Haematol 1996;96:150-154. 
13 Beutler E, Blume KG, Kaplan JC: International Committee for Standardization in Haematology: Recommended screening test for glucose-6-phosphate dehydrogenase (G6PD) deficiency. Br J Haematol 1979;43:469-477.

14 Poncz M, Solowiejczyk D, Harpel B, Mory Y, Schwartz E, Surrey S: Construction of human gene libraries from small amounts of peripheral blood: Analysis of $\beta S$-like globin genes. Hemoglobin 1982;6:27-36.

15 Baysal E, Huisman THJ: Detection of common deletional $\alpha$-thalassemia-2 determinants by PCR. Am J Hematol 1994;46:208-213.

16 Orkin SH, Goff SC, Hechtman RL: Mutation in an intervening sequence splice junction in man. Proc Natl Acad Sci USA 1981;78:50415045 .
17 Adekile AD: Historical and anthropological correlates of $\beta$ S haplotypes and $\alpha$ - and $\beta$-thalassemia alleles in the Arabian Peninsula. Hemoglobin 1997;21:281-296.

18 Hayakawa A, Sano K, Hasegawa D, Kosaka Y, Nakamura H, Ideguchi H, Harano T: Hereditary hemoglobin $\mathrm{H}$ disease in Japanese siblings diagnosed by human parvovirus B19 infection. Rinsho Ketsueki 1999;40:536-541.

19 Kellermayer R, Faden H, Grossi M: Clinical presentation of parvovirus B19 infection in children with aplastic crisis. Pediatr Infect Dis J 2003;22:1100-1101.

20 Badr MA: Human parvovirus B19 infection among patients with chronic blood disorders. Saudi Med J 2002;23:295-297.

-21 Sanna G, Frau F, Melis MA, Galanello R, De Virgiliis S, Cao A: Interaction between the glucose-6-phosphate dehydrogenase deficiency and thalassaemia genes at phenotype level. $\mathrm{Br}$ J Haematol 1980;44:555-561.
22 Öner C, Öner R, Birben E, Balkan H, Gümruk F, Gürgey A, Altay Ç: Hb $\mathrm{H}$ disease with homozygosity for red cell G6PD deficiency in a Turkish female. Hemoglobin 1998;22:157160

23 Matthay KK, Mentzer WC, Dozy AM, Kan YW and Bainton DF: Modification of hemoglobin $\mathrm{H}$ disease by sickle cell trait. J Clin Invest 1979;64:1024-1032.

24 Adams RJ, Kutlar A, McKie V, Carl E, Nichols FT, Liu JC, Mckie K, Clary A: Alpha thalassemia and stroke in sickle cell anemia. Am J Hematol 1994;45:279-282.

5 Steinberg MH: Modulation of the phenotypic diversity of sickle cell anemia. Hemoglobin 1996;20:1-19. 